\title{
Lignin and stem flexibility in eucalyptus seedlings subjected to hardening
}

\author{
Lignina e flexibilidade caulinar em mudas de eucalipto submetidas a rustificação
Paulo Ricardo Lima', Ubirajara Contro Malavasi' ${ }^{I I}$, Maycom Marinho Lopes ${ }^{\mathrm{III}}$, João Alexandre Lopes Dranski ${ }^{\mathrm{v}}$, Marlene de Matos Malavasi ${ }^{\mathrm{v}}$, Flavio Gurgacz ${ }^{\mathrm{VI}}$, Augustinho Borsoi ${ }^{\mathrm{VII}}$

\begin{abstract}
The objective of this work was to verify if hardening by stem bending and foliar spray of jasmonic acid (JA) induced lignification and if it altered the post-planting development. The experiment was initially conducted in a shade house following a completely randomized design with treatments as (T1) control; (T2) $2.0 \mu \mathrm{mol} \mathrm{L} \mathrm{L}^{-1}$ of JA; (T3) $4.0 \mu \mathrm{mol} \mathrm{L}^{-1}$ of JA; (T4) $6.0 \mu \mathrm{mol} \mathrm{L}-1$ of JA; (T5) $8.0 \mu \mathrm{mol} \mathrm{L}^{-1}$ of JA; (T6) 20 stem bending; (T7) 40 stem bending and five replicates. At the end of the imposed treatments, we calculated the increments in height, stem diameter, number of leaves, root and shoot dry biomasses, as well as the lignin content of shoots and roots and the stem stiffness. Afterwards, seedlings were planted following a randomized block design with three seedlings per replicate. At 90 and 150 days after planting, we quantified increments in height and stem diameter. Treatments T5 and T6 showed higher bending strength $(0.28885$ and $0.3005 \mathrm{~N}$ $\mathrm{cm}^{-1}$, respectively). Seedlings submitted to doses above $6.0 \mu \mathrm{mol} \mathrm{L}^{-1}$ of JA (T5) and imposition of stem bending (T6 and T7) resulted in a higher stem lignin content. The smaller doses of JA (T2, T3 and T4) and 20 stem bending (T6) resulted in seedlings with a relative increase in diameter. The interpretation of path analysis showed weak multicollinearity, that is, the variables under study are not highly correlated and there was a greater direct correlation between the lignin content of the stem with the mean increase in height and diameter of the seedlings after planting.
\end{abstract}

Keywords: Seedling hardening; Eucalyptus urophylla x Eucalyptus grandis; Seedling quality; Phytoregulator

\section{Resumo}

O trabalho objetivou verificar se a rustificação por flexões caulinares e a pulverização foliar com ácido jasmônico (JA) induz lignificação e altera o desenvolvimento pós-plantio. O experimento iniciou em ambiente protegido seguindo um delineamento inteiramente ao acaso com sete tratamentos (T1) testemunha; (T2) 2,0 $\mu \mathrm{mol} \mathrm{L}^{-1} \mathrm{de} \mathrm{JA}$; (T3) 4,0 $\mu \mathrm{mol} \mathrm{L}^{-1} \mathrm{de}$ JA; (T4) 6,0 $\mu \mathrm{mol} \mathrm{L}^{-1}$ de JA; (T5) 8,0 $\mu \mathrm{mol} \mathrm{L}^{-1}$ de JA; (T6) 20 flexões; (T7) 40 flexões e cinco repetições. Ao final da aplicação dos tratamentos, avaliaram-se os incrementos na altura, no diâmetro do coleto e número de folhas, assim como o teor de lignina dos tecidos caulinares, das raízes e a rigidez flexural. Em seguida, as mudas rustificadas foram plantadas a campo em delineamento em blocos ao acaso com três mudas por repetição. Aos 90 e 150 dias, avaliaram-se os incrementos na altura e no diâmetro do caule. Mudas dos tratamentos T5 e T6 apresentaram maior resistência à curvatura $(0,2885$ e 0,3005 $\mathrm{N} \mathrm{cm}^{-1}$, respectivamente). $\mathrm{O}$ teor de lignina no caule aumentou com aplicações de JA acima de $6,0 \mu \mathrm{mol} \mathrm{L}^{-1} \mathrm{e}$ imposição de flexões caulinares. As menores doses de JA (T2, T3 e T4) e o tratamento com 20 flexões caulinares (T6) resultaram em mudas com aumento no incremento no diâmetro do caule. A interpretação da análise de trilha demonstrou que houve aumento na rigidez do caule acompanhado com o aumento no teor de lignina e que estes possuem um maior efeito direto inversamente proporcional com o incremento médio em altura e com o diâmetro do caule após o plantio.

Palavras-chave: Rustificação de mudas; Eucalyptus urophylla x Eucalyptus grandis; Qualidade de mudas; Fitoregulador

\footnotetext{
1 Engenheiro Agrônomo, Dr., Professor do Curso de Tecnologia em Gestão Ambiental, Universidade Estadual de Mato Grosso do Sul, BR-163, Km 20,2, CEP 79980-000, Mundo Novo (MS), Brasil. paulorikardoo@hotmail.com (ORCID: 0000-0003-3313-0613)

II Engenheiro Florestal, Dr., Professor do Programa de Pós-Graduação em Agronomia, Centro de Ciências Agrárias, Universidade Estadual do Oeste do Paraná, Rua Pernambuco, 1777, CEP: 85960-000, Marechal Cândido Rondon (PR), Brasil. biramalavasi@yahoo.com.br (ORCID: 0000-0003-43004338)

III Zootecnista, MSc., Pesquisador Autônomo, Rua Coruripe, 17, CEP: 69.087-074, Manaus (AM), Brasil. maycomarinho@hotmail.com (ORCID: 00000003-2693-9721)

IV Biólogo, Dr., Professor do Curso de Agronomia, Faculdade Educacional de Medianeira, Rua Rio Branco, 1820, CEP: 85884-000, Medianeira (PR), Brasil. joaodranski@yahoo.com.br (ORCID: 0000-0002-2460-7865)

Engenheira Agrônoma, Dra., Professora do Programa de Pós-Graduação em Agronomia, Centro de Ciências Agrárias, Universidade Estadual do Oeste do Paraná, Rua Pernambuco, 1777, CEP: 85960-000, Marechal Cândido Rondon (PR), Brasil.marlenemalavasi@yahoo.com.br (ORCID: 00000002-6726-6490)

vı Engenheiro Agrônomo, Dr., Professor na Universidade Estadual do Oeste do Paraná, Rua Universitária, 1619, CEP 85819-170, Cascavel (PR), Brasil. flavio.gurgacz@unioeste.br (ORCID: 0000-0002-4001-7072)

vII Engenheiro Agrônomo, Dr., Professor do Curso de Agronomia, Centro Universitário Assis Gurgacz, Avenida das Torres, 500, CEP 85806-095, Cascavel (PR), Brasil. augustinho.borsoi@outlook.com (ORCID: 0000-0002-1361-5464)
} 


\section{Introduction}

The use of quality seedlings is necessary to guarantee the success of planting and the establishment of a forest stand (PANDOLFI, 2009). High-quality seedlings are those that best adapt to adverse the post-planting condition, provide a high percentage of survival and a rapid initial growth. However, the concept of seedling quality is relative because the quality standard is different between species and planting sites, making a challenge for many forestry companies.

The production of resistant seedlings capable of surviving and tolerating post-planting stresses is one of the possible alternatives to minimize post-planting losses. The quality of seedlings from woody species is based on various morphological characteristics related to survival and initial growth after planting and consequently to success of forest establishment. Characteristics such as seedling height and stem diameter are frequent quality attributes (CARNEIRO, 1995; RITCHIE et al., 2010).

On the other hand, the concentration of lignin in seedlings of woody species is not recognized as a quality attribute. However, it is notable that lignin plays an important role in wood species (MALAVASI; DAVIS; MALAVAS, 2016). After cellulose, lignin is the most abundant organic substance in plants. Lignin is a phenolic macromolecule with several functions, among which are the rigidity necessary to maintain the verticality of the stem and the existence of fast water circulation paths through the xylem. In addition to mechanical support, lignin is related to plant defense against herbivores, because it is hardly digestible (MONTEIRO; PEREIRA; ABREU, 2012; TAIZ; ZEIGER, 2013). Thus, it is reasonable to infer that there is a relationship between lignin concentration and seedling quality.

Several authors have indicated that some nursery practices, such as the submission of seedlings to mechanical stimuli and plant regulators, may be related to the hardening of woody species (JACOBS; LANDIS, 2009; ORO et al., 2011; DRANSKI, 2013; VOLKWEIS et al., 2014; CADORIN et al., 2015). Thus, such practices could be included in the production protocol of a nursery to induce seedling hardening. Dranski, Malavasi and Malavasi (2015) reported significant changes in the lignin content in both root and shoot systems of Pinus taeda L. seedlings submitted to mechanical stimuli.

Mechanical perturbation can induce responses in plants through stem bending (JAFFE, 1973). Plant responses to those stimuli vary among species but are common to a number of woody species such as the reduction of cellular elongation with consequent reduction in the seedling height and the increase in the stem diameter (KERN et al., 2005; DRANSKI, 2013; VOLKWEIS et al., 2014; CADORIN et al., 2015). The mechanical stimulus is difficult to operate in nurseries, which justifies the use of other methods such as the application of plant regulators also responsible for changes in lignin biosynthesis in plants. In an experiment conducted by Oliveira, Abreu and Pereira (2009), applications of jasmonic acid resulted in increased lignin content in Eucalyptus urophylla S. T. Blake.

Jasmonic acid and its derivatives jasmonates are endogenous plant growth regulators originating linolenic acid, which occur in various plant species and are related to the plant senescence, leaf abscission, embryo development and defense mechanism acting as stress flags (FRANK; ROSS, 1991; KERBAUY, 2012).

Eucalyptus clone 1528, named as "superclone" according to Portal Florestal (2016), presents genetic basis of Eucalyptus urophylla and Eucalyptus grandis with an annual average increment of 50 $\mathrm{m}^{-3} \mathrm{ha}^{-1}$ year ${ }^{-1}$, wood density of $531 \mathrm{~kg} \mathrm{~m}^{-3}$, total lignin content of $29.24 \%$, holocellulose content of $68.14 \%$, gravimetric yield of $50.41 \%$ and mechanical strength of $80.82 \%$. The clone aims at plants with good growth characteristic of Eucalyptus grandis as well as an increase in wood density and improvements in the yield and physical properties of the cellulose characteristic of Eucalyptus urophylla (CARVALHO; NAHUZ, 2001).

Seedling hardening by stem bending and jasmonic acid cause physiological responses which may result in higher field performance. Therefore, this experiment aimed to test if hardening by stem bending or jasmonic acid induces stem lignification and if such lignification correlates with the initial field development of hybrid eucalyptus from 1528 seedlings. 


\section{Material and methods}

The experiment was conducted from January to May of 2016. The experiment was conducted initially in a shade house located at $24^{\circ} 33^{\prime} \mathrm{S}$ and $54^{\circ} 02^{\prime} \mathrm{W}$ and altitude of $414 \mathrm{~m}$, while field trial was performed in an area located at $24^{\circ} 31^{\prime} \mathrm{S}$ and $54^{\circ} 01^{\prime} \mathrm{W}$ and altitude of $363 \mathrm{~m}$.

The regional climate according to Köppen is a Cfa subtropical with average temperature of the coldest month below $18^{\circ} \mathrm{C}$ and average temperature in the warmer month above $22^{\circ} \mathrm{C}$, with infrequent frost and tendency to concentration rainfall in the summer months and an annual precipitation from 1,600 to $1,800 \mathrm{~mm}$ (CAVIGLIONE et al., 2000).

Seedlings of clone 1528 were propagated by mini cuttings in $50 \mathrm{~cm}^{3}$ tubes filled with commercial substrate (Plantmax ${ }^{\circledR}$ ), fertilized with $300 \mathrm{~g}$ per $25 \mathrm{Kg}$ bag of substrate of controlledrelease fertilizer (Basacote ${ }^{\circledR}$ Plus $6 \mathrm{M}$ of formulation $\mathrm{N}_{2}-\mathrm{P}_{2} \mathrm{O}_{5}-\mathrm{K}_{2} \mathrm{O}$ 16-8-12). Seedlings with a height of $23.58 \pm 1.16 \mathrm{~cm}$ and stem diameter of $2.70 \pm 0.13 \mathrm{~mm}$ were placed in a shade house which consisted of a galvanized iron structure with an arc-shaped roof of $7 \times 30 \mathrm{~m}$ and $3.5 \mathrm{~m}$ of height. The ceiling was covered with low-density polyethylene (LDPE) and anti-UV $150 \mu \mathrm{m}$ thick plastic film while the sides were protected by a $30 \%$ white shading screen.

The experimental followed a completely randomized design with five replicates of twenty seedlings. Treatments were: control with deionized water + nonionic surfactant applied weekly for four weeks (T1); $2.0 \mu \mathrm{mol} \mathrm{L}-1$ of jasmonic acid + deionized water + nonionic surfactant applied weekly for 4 weeks (T2); $4.0 \mu \mathrm{mol}$ of jasmonic acid + deionized water + nonionic surfactant applied weekly for four weeks (T3); $6.0 \mu \mathrm{mol}$ of jasmonic acid + deionized water + nonionic surfactant for four weeks (T4); $8.0 \mu \mathrm{mol}$ of jasmonic acid + deionized water + nonionic surfactant applied for four weeks (T5); 20 daily stem bending for four weeks + deionized water and non-ionic surfactant (T6); 40 daily stem bending for four weeks + deionized water and non-ionic surfactant applied weekly (T7). The nonionic surfactant used was AGRAL ${ }^{\circledR}$ following the manufacturer's instructions.

Jasmonic acid was applied once a week by spraying at the concentration according to each treatment described above, with a total volume of the solution equivalent to $7 \mathrm{~mL}$ per seedling with manual sprayer at a pressure of $0.3 \mathrm{MPa}$. The surfactant was used to improve the distribution and foliar absorption of the applied product by reducing the surface tension of the droplets and to reduce the angle of contact with the leaf surface.

The stem bending was performed daily through the double passage of a structure composed of a $25 \mathrm{~mm}$ diameter PVC tube arranged horizontally and fixed in a metallic structure with bearings. Seedlings were vertically bent no more than $45^{\circ}$ by passing the bar in the lower third of the foliage always at the same time at $0.10 \mathrm{~m} \mathrm{sec}^{-1}$ (VOLKWEIS et al., 2014).

During the application of the treatments irrigation occurred daily in the early morning and late afternoon until saturation.

At the end of the treatments, we randomly selected twenty seedlings per replicate for calculation of height and diameter increments as well as number of leaves. Four seedlings of those twenty per replicate were also randomly selected to calculate the increments in below and above ground dry biomasses.

We performed lignin extraction from stem and roots tissues through acid hydrolysis according to Detmann et al. (2012) in twenty-five seedlings per treatment. The lignin content was determined by Lignin $(\%)=[(\operatorname{Res}$ As - Res c $) *(100 / 2 * \mathrm{MA})] /$ MA, where Res As is dry matter resulting from sulfur digestion, Res $\mathrm{c}$ is dry matter resulting from carbonization and MA is the initial dry biomass.

For the evaluation of flexural stiffness, the resistance of stem in twenty-five seedlings we used a system (Figure 1) composed by a digital scale and a caliper. 


\section{Figure 1 - Apparatus constructed to quantify the resistance of the seedling stems}

Figura 1 - Aparato construído para quantificação da resistência do caule em mudas

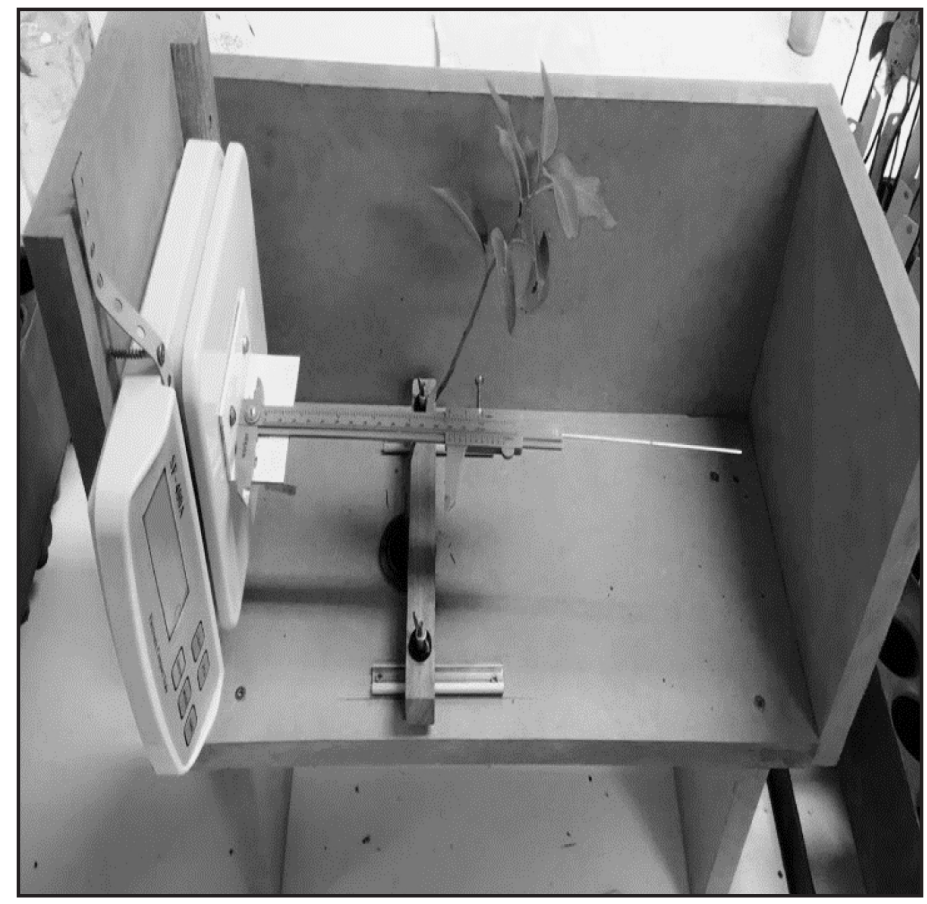

Source: Authors (2017)

To quantify the resistance, a high accuracy electronic Sf-400 Digital Scale (1 to $10 \mathrm{~kg}$ ) and a $200 \mathrm{~mm}$ caliper were fixed to a wooden structure. We used the caliper to pull the seedling stem to distances of 1,2 and $3 \mathrm{~cm}$ from the axis. We recorded readings about 3 seconds after the stem pull for stabilization of the scale. Values of weight and distance were converted to resistance and expressed in Newton $\left(\mathrm{N} \mathrm{cm}^{-1}\right)$.

After hardening treatments, we randomly selected three seedlings per replicate for field trial which followed a randomized block design. Planting occurred in July 2016 and climate data of the period is graphed in Figures 2 and 3.

According to Bhering (2007), regional soil is classified as Dystroferric Red Latosol (known as Oxisol) from very clayey texture (SANTOS et al., 2013). Soil characteristics included: $\mathrm{pH}\left(\mathrm{CaCl}_{2}\right)$ $=5.3 ;$ Organic matter $=13.40 \mathrm{~g} \mathrm{dm}^{-3} ; \mathrm{P}=1.32 \mathrm{mg} \mathrm{dm}^{-3} ; \mathrm{Ca}^{2+}=4.30 \mathrm{cmolc} \mathrm{dm}^{-3} ; \mathrm{Mg}^{2+}=2.20 \mathrm{cmolc}^{-}$ $\mathrm{dm}^{-3} ; \mathrm{K}^{+}=0.23 \mathrm{cmolc} \mathrm{dm}^{-3} ; \mathrm{Al}^{3+}=0.0 \mathrm{cmolc} \mathrm{dm}^{-3} ; \mathrm{H}+\mathrm{Al}=3.42 \mathrm{cmolc} \mathrm{dm}^{-3} ; \mathrm{SB}=6.73 \mathrm{cmolc} \mathrm{dm}^{-3} ;$ CTC $=10.15 \mathrm{cmolc} \mathrm{dm}^{-3}$ and $\mathrm{V} \%=66.31 \%$.

Planting used 27 by $50 \mathrm{~cm}$ holes in a $3 \times 2 \mathrm{~m}$ spacing with $100 \mathrm{~g}$ per planting hole of $\mathrm{N}_{2}-$ $\mathrm{P}_{2} \mathrm{O}_{5}-\mathrm{K}_{2} \mathrm{O}$ (5-25-25) and weeding every thirty days. At ninety and one hundred and fifty days after planting we measured and calculated height and stem diameter increments.

Data was evaluated for normality of the distribution of the residues by the Lilliefors test, and for the homogeneity of the variance by the Cochran and Bartlet test followed by analysis of variance at the significance level of 0.05 . Lignin content in the stem and roots, plant height and stem diameter were analyzed following a completely randomized design. For stem resistance, the data analysis followed a completely randomized design in subdivided plots with treatments comprised by plots and the pull distances in the subplots. For the analysis of height and stem diameter increments from field planted seedling data, it was analyzed in a split - plot design, in which the plots were considered the treatments and the evaluation period the subplots. When necessary, means were compared by the Tukey test at $5 \%$ of error probability. 
Figure 2 - Decendial meteorological data of rainfall and average temperature between May 2016 and January 2017

Figura 2 - Dados meteorológicos decendiais de precipitação pluviométrica e temperatura média entre os meses de maio de 2016 a janeiro de 2017

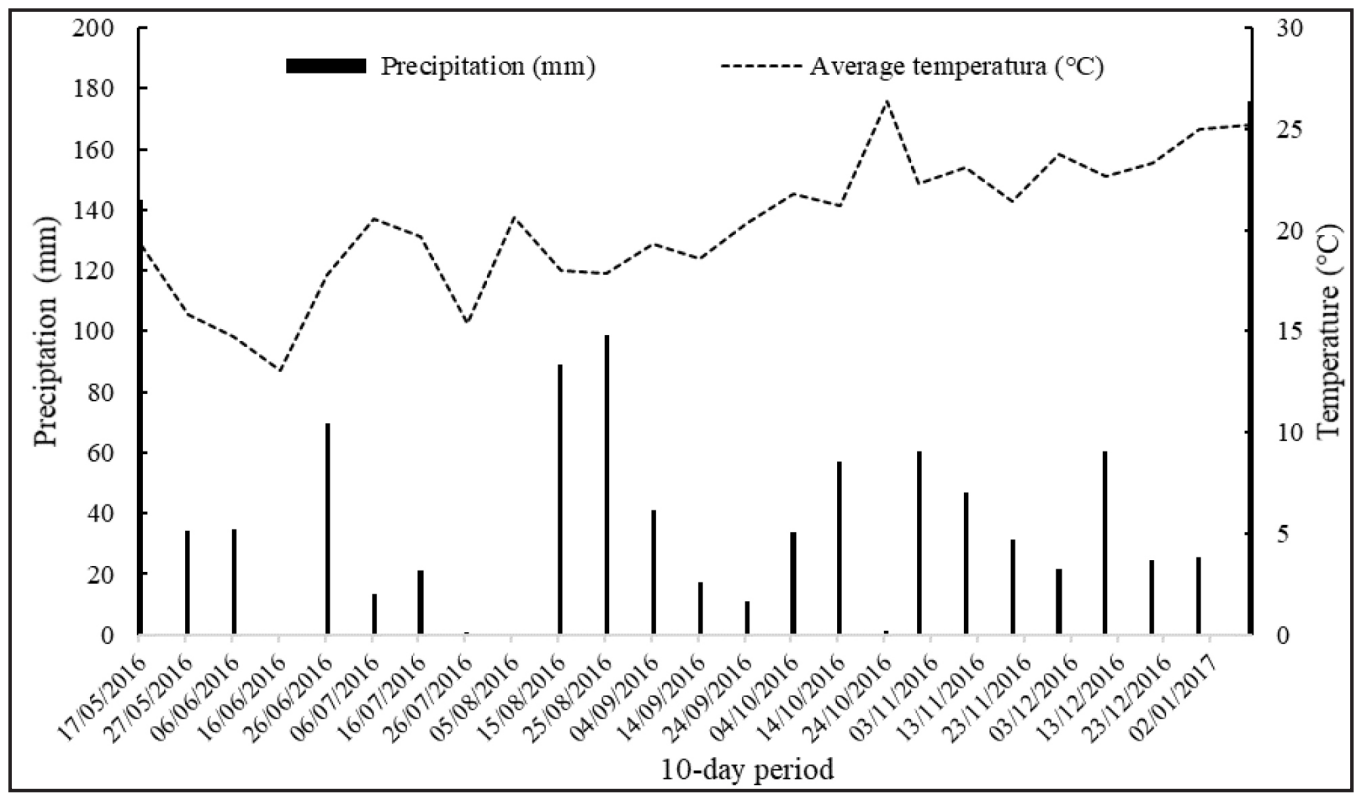

Source: Estação Meteorológica de Observação de Superfície Automática do INMET (2016)

Figure 3 - Decendial meteorological data of mean wind speed between July 2016 and February 2017

Figura 3 - Dados meteorológicos decendiais de velocidade média do vento entre os meses de julho de 2016 a fevereiro de 2017

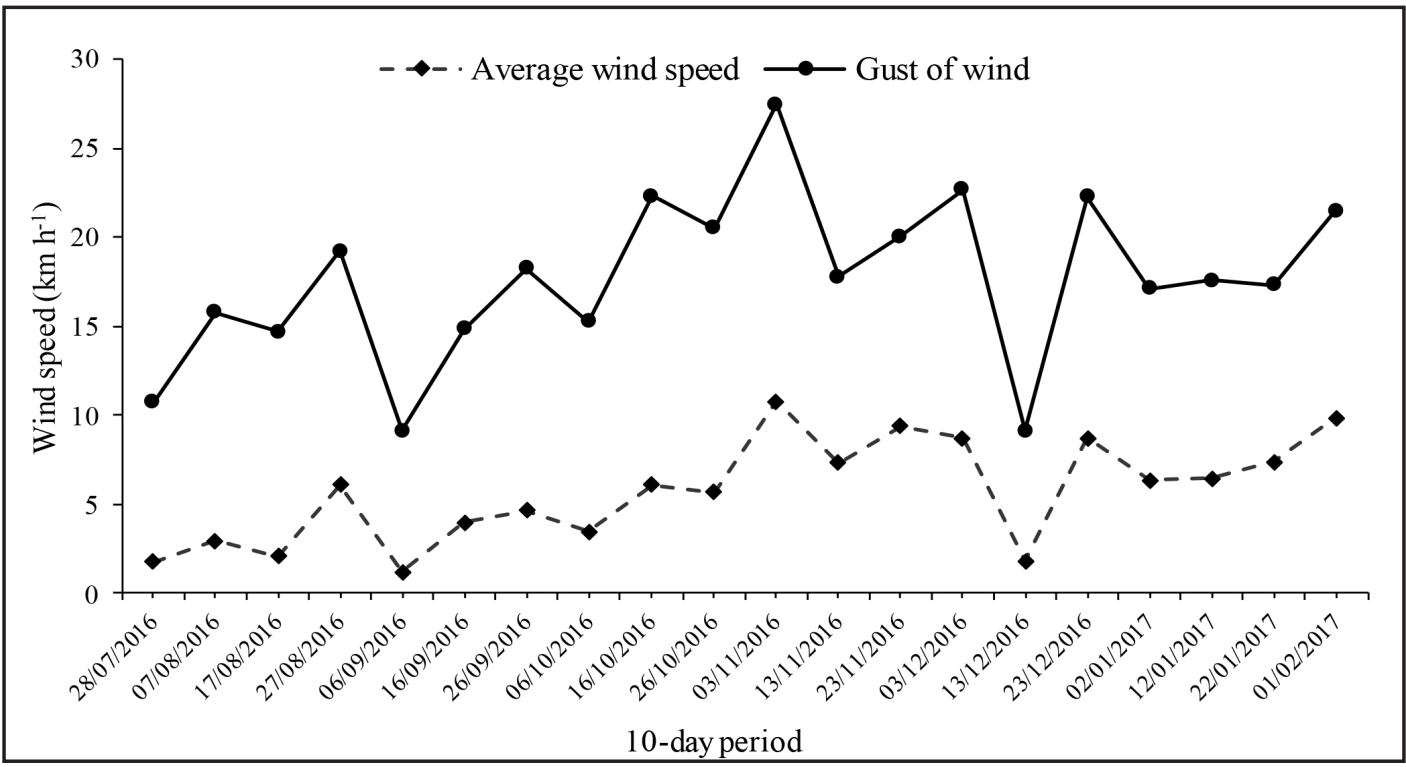

Source: Estação Meteorológica de Observação de Superfície Automática do INMET (2016) 
Based on the results of the variables evaluated in the nursery and in the field, Pearson correlation indexes were calculated and then the multicollinearity diagnosis performed, based on the condition number (NC) and the factor of inflation of variance (FIV). Later, we conducted a path analysis in which height and stem diameter increments were considered as dependent variables. To perform the statistical analysis, we used GENES (CRUZ, 2001).

\section{Results and discussion}

Results of stem resistance showed that seedlings from T5 and T6 presented greater values than seedlings from the other treatments (Table 1). These results suggest that seedlings of Eucalyptus clone 1528, submitted to the application of the highest dose of JA (T5), expressed morphological responses that resemble those from the lower frequency of stem bending (T6).

Table 1 - Stem resistance from seedlings submitted to JA and stem bending as a function of distance pull

Tabela 1 - Quantificação da rigidez caulicular em mudassubmetidas JA e flexões caulinares em função da distância

\begin{tabular}{|c|c|c|c|c|}
\hline \multirow{2}{*}{ Treatments } & $1 \mathrm{~cm}$ & $2 \mathrm{~cm}$ & $3 \mathrm{~cm}$ & \multirow{2}{*}{ Average } \\
\hline & \multicolumn{3}{|c|}{$\mathrm{N} \mathrm{cm}{ }^{-1}$} & \\
\hline T1 & 0,2402 & 0,2356 & 0,2010 & $0,2256 \mathrm{bc}$ \\
\hline T2 & 0,1845 & 0,1897 & 0,1835 & $0,1932 \mathrm{c}$ \\
\hline T3 & 0,2389 & 0,2359 & 0,2039 & $0,2262 \mathrm{bc}$ \\
\hline T4 & 0,2672 & 0,2605 & 0,2237 & $0,2505 \mathrm{~b}$ \\
\hline T5 & 0,3009 & 0,2887 & 0,2760 & $0,2885 \mathrm{a}$ \\
\hline T6 & 0,3230 & 0,3087 & 0,2698 & $0,3005 \mathrm{a}$ \\
\hline $\mathrm{T} 7$ & 0,2784 & 0,2609 & 0,2229 & $0,2541 \mathrm{~b}$ \\
\hline Average & $0,2619 \mathrm{~A}$ & $0,2543 \mathrm{~A}$ & $0,2258 \mathrm{~B}$ & \\
\hline \multicolumn{5}{|c|}{ F calculated for treatments $=18,53 ; p<0,001$} \\
\hline \multicolumn{5}{|c|}{ F calculated for distance $=10,103 ; p<0,001$} \\
\hline \multicolumn{5}{|c|}{ F calculated interaction $=0,39 ; p=0,962$} \\
\hline CV (\%) & \multicolumn{4}{|c|}{16,6} \\
\hline
\end{tabular}

Source: Authors (2017)

On what: Average followed by the same capital letter in the row and lowercase in the column do not differ statistically from each other, by the Tukey test at $5 \%$ probability. $\mathrm{N} \mathrm{cm}^{-1}$ (Newton $\mathrm{cm}^{-1}$ ); (T1) control; (T2) 2,0 $\mu \mathrm{mol} \mathrm{L}^{-1}$ de JA; (T3) 4,0 $\mu \mathrm{mol} \mathrm{L}{ }^{-1}$ de JA; (T4) 6,0 $\mu \mathrm{mol} \mathrm{L}^{-1}$ de JA; (T5) 8,0 $\mu$ mol L-1 de JA; (T6) 20 stem flexures; (T7) 40 stem flexures.

According to Martin et al. (2010) and Telewski (2012), mechanical perturbation or thigmomorphogenesis affects the mechanical behavior of the stem, modifying the cell differentiation which induces anatomical alterations that decrease stem elasticity. This increase in the stem stiffness may be capable of absorbing energy in response to wind. 
Plant growth regulators such as JA are promising in reducing crop sensitivity to abiotic stresses, because those molecules may attenuate adverse effects produced by different environmental stressors such as water stress (MARDANI et al., 2012). Sanchez (2008) with hybrid Eucalyptus grandis $\mathrm{x}$ Eucalyptus urophylla reported that the application of JA and methyl jasmonate may have interfered in the perception of stress signals, resulting in greater efficiency in stomatal closure and the reduction of transpiration.

It is also notable the significant difference in the mean values of the stem resistance in function of the pull distance used (Table 1) as the tension increased. Therefore, it may be important to further studies to understand plant responses due to the imposition of levels of bending induction of seedling stems from wood species.

Seedlings from $\mathrm{T} 6$ and $\mathrm{T} 7 \mathrm{had}$ lower root lignin content compared to the others treatments (Table 2) except from seedlings subjected to the highest dose of JA. An interpretation of the above can result by the higher allocation of lignin to the stem tissues, because T4, T5, T6 and T7 showed higher lignin concentration in above ground tissues compared to other treatments. The results suggested that seedlings of Eucalyptus clone 1528 submitted to the application of the two higher doses of JA expressed responses to the concentration of stem lignin that resembled those from stem bending.

Monteiro, Pereira and Abreu (2012), working with Eucalyptus urophylla submitted to application of JA and 2,4-dichlorophenoxyacetic acid reported that those molecules can activate or inhibit the polymerization phase of the lignin depending on the concentration used. According to those same authors, plant growth regulators act as signals in the plant and the synthesis of lignin can be affected by several abiotic and biotic factors. This fact suggests that the two higher doses of JA used in this experiment were able to act as stress signals, altering lignin synthesis. In addition, Kavalier (2000) reported that JA is one of the signaling molecules that initiates the activation of phenylalanine ammonia-lyase an enzyme of the phenylpropanoid pathway, listed as biosynthetic route of lignin formation and other secondary metabolites.

Results that partially corroborate with those of this experiment were reported by Oliveira, Abreu and Pereira (2009) who verified a change in lignin content of Eucalyptus urophylla seedlings when submitted to the application of 1 and $2 \mu \mathrm{mol} \mathrm{L}^{-1}$ of JA. The lower concentration of JA resulted in a significant increase in the lignin content (41.56\%) compared to the control seedling whereas the application of $2 \mu \mathrm{mol} \mathrm{L}^{-1}$ showed an inhibitory effect reducing lignin by $20.49 \%$.

Lignin in the stem from bending treatments were corroborated by Porter et al. (2009), that worked with mechanical stimuli in papaya seedlings and noted an increase of approximately $12 \%$ in lignin concentration in the stimulated seedlings.

Seedlings submitted to stem bending presented a smaller increase in height in relation to the other treatments, but did not differ from the seedlings submitted to the application of 6.0 $\mu$ mol L-1 of JA (Table 2).

Regarding the increment in the stem diameter, it was evidenced that, seedlings from the control treatment and seedlings submitted to the application of the highest dose of JA (T5), presented a smaller increase in relation to those submitted to 20 stem bending, but both did not differ from the other treatments. Therefore, seedlings from clone 1528 submitted to the application of stem bending increased the stem diameter in comparison to the control seedlings. The above results are similar to several published reports (KERN et al., 2005; DRANSKI, 2013; VOLKWEIS et al., 2014; CADORIN et al., 2015). 
The seedling height is easy to measure and is widely used to evaluate the seedling quality of wood species, while the stem diameter is important for the evaluation of survival and growth after planting. Seedlings with larger stem diameter generally have higher field survival because of the ability to form new roots (HAASE, 2008).

Table 2 - Lignin content in root and in stem, increment in plant height and in stem diameter in Eucalyptus seedlings clone 1528 submitted to application of jasmonic acid and stem bending

Tabela 2 - Teor de lignina na raiz e no caule, incremento na altura e no diâmetro do coleto em mudas de eucalipto clone 1528 submetidas à aplicação de ácido jasmônico e flexões caulinares

\begin{tabular}{|c|c|c|c|c|}
\hline \multirow{2}{*}{ Treatments } & LR & LC & IAP & IDC \\
\hline & \multicolumn{2}{|c|}{$\%$} & $\mathbf{c m}$ & $\mathbf{m m}$ \\
\hline T1 & $27,40 \mathrm{a}$ & $13,17 \mathrm{~b}$ & $3,607 \mathrm{ab}$ & $0,372 \mathrm{~b}$ \\
\hline $\mathbf{T} 2$ & $26,65 \mathrm{a}$ & $13,14 b$ & $3,780 \mathrm{a}$ & $0,470 \mathrm{ab}$ \\
\hline T3 & $26,62 \mathrm{a}$ & $13,27 \mathrm{~b}$ & $4,020 \mathrm{a}$ & $0,527 \mathrm{ab}$ \\
\hline $\mathbf{T 4}$ & $26,70 \mathrm{a}$ & $14,44 \mathrm{a}$ & $2,707 \mathrm{abc}$ & $0,592 \mathrm{ab}$ \\
\hline T5 & $25,06 \mathrm{ab}$ & $14,22 \mathrm{a}$ & $3,995 \mathrm{a}$ & $0,437 \mathrm{~b}$ \\
\hline T6 & $24,17 \mathrm{~b}$ & $14,65 \mathrm{a}$ & $1,960 \mathrm{bc}$ & $0,702 \mathrm{a}$ \\
\hline T7 & $23,98 \mathrm{~b}$ & $14,62 \mathrm{a}$ & $1,022 \mathrm{c}$ & $0,545 \mathrm{ab}$ \\
\hline
\end{tabular}

F calc to $\mathrm{LR}=7, \mathbf{5 1} ; p<\mathbf{0 , 0 0 1})$

F calc to $\mathrm{LC}=21,68 ; p<0,001)$

F calc to IAP $=8.92 ; p<0,001$

F calc to $\mathrm{IDC}=3,64 ; p<0,05)$

\begin{tabular}{lllll}
\hline $\mathbf{C V}(\%)$ & 3,9 & 3,4 & 25 & 21 \\
\hline
\end{tabular}

Source: Authors (2017)

On what: Average followed by the same lowercase letter in the column do not differ statistically from each other, by the Tukey test at 5\% probability. T1: witness; T2: $2,0 \mu \mathrm{mol} \mathrm{L}{ }^{-1} \mathrm{de} \mathrm{JA}$; T3: $4,0 \mu \mathrm{mol} \mathrm{L}^{-1} \mathrm{de}$ JA; T4: 6,0 $\mu \mathrm{mol} \mathrm{L} \mathrm{L}^{-1} \mathrm{de}$ JA; T5: 8,0 $\mu \mathrm{mol} \mathrm{L}{ }^{-1}$ de JA; T6: 20 stem flexures; T7: 40 stem flexures; LR: root lignin; LC: stem lignin; IAP: height increment; IDC: stem diameter increment.

One hundred and fifty days after planting, seedlings from T2 (the lowest JA dose) presented a higher average growth in relation to the seedling from other JA treatments and the lowest frequency of stem bending (Table 3). These results suggested that seedlings submitted to the application of the highest dose of JA acid and to the mechanical stimulation by stem bending, which presented a higher concentration of lignin in the stem and greater stem resistance, did not result in faster growth after planting. 
Table 3 - Increase in height and stem diameter of seedlings of clone 1528 in the field after being submitted to application of JA and stem bending at 90 and 150 days after field planting

Tabela 3 - Incremento em altura e diâmetro do coleto em mudas de eucalipto clone 1528 a campo após serem submetidas à aplicação de ácido jasmônico e flexões caulinares avaliadas aos

90 e 150 dias após o transplantio

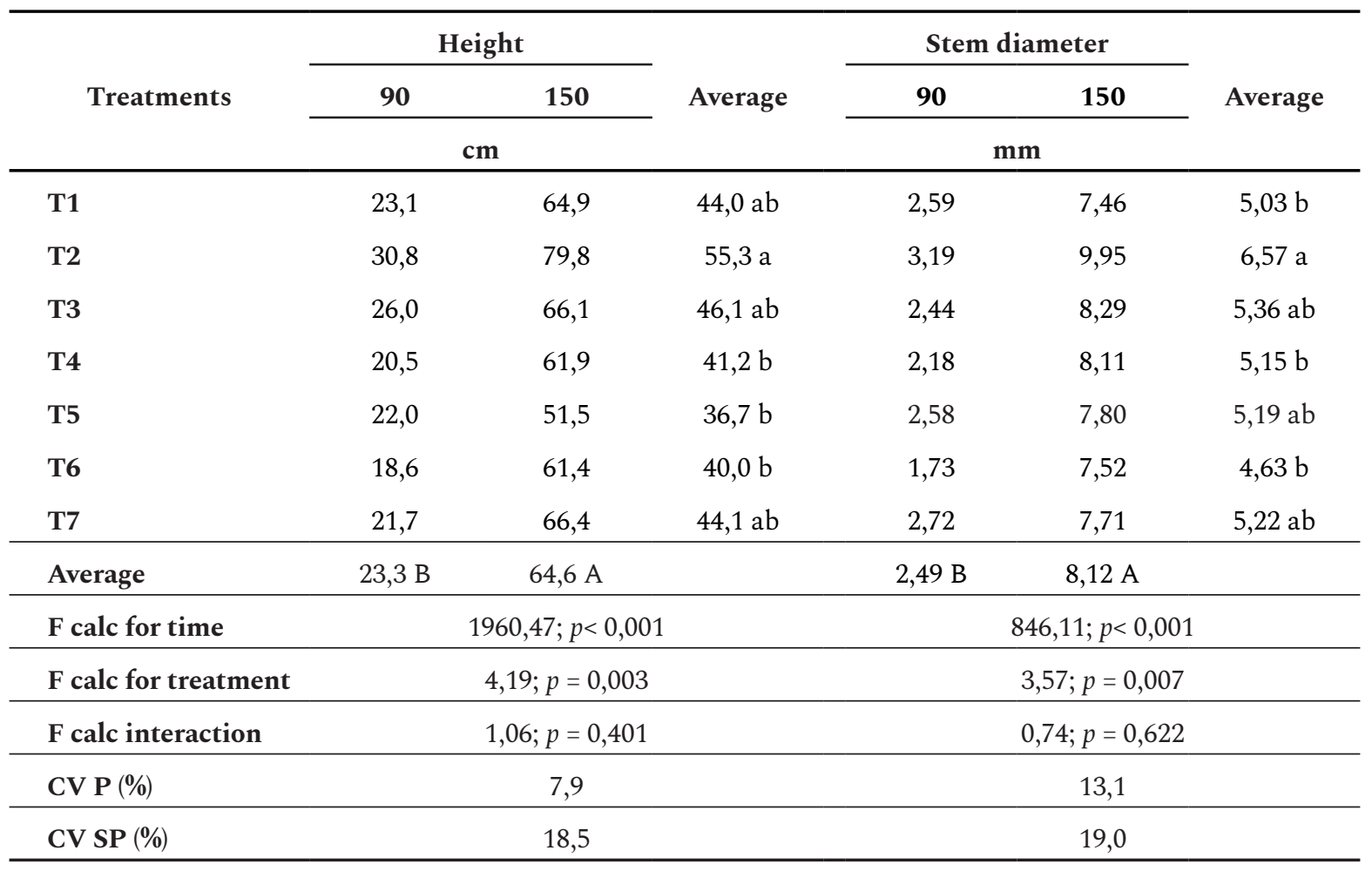

Source: Authors (2017)

On what: Average followed by the same capital letter in the row and lowercase in the column do not differ statistically from each other, by the Tukey test at $5 \%$ probability. T1: witness; T2: $2,0 \mu \mathrm{mol} \mathrm{L}^{-1} \mathrm{de} \mathrm{JA}$; T3: $4,0 \mu \mathrm{mol}$ $\mathrm{L}^{-1}$ de JA; T4: 6,0 $\mu \mathrm{mol} \mathrm{L} \mathrm{L}^{-1}$ de JA; T5: 8,0 $\mu \mathrm{mol} \mathrm{L} \mathrm{L}^{-1}$ de JA; T6: 20 stem flexures; T7: 40 stem flexures. P: parcels; SP: subplots.

In a work with salicylic acid (SA) and water deficit in hybrid eucalyptus seedlings (Eucalyptus urophylla $\mathrm{x}$ Eucalyptus grandis), Mazzuchelli, Souza and Pacheco (2014) concluded that the application of SA could positively affect the growth and development of eucalyptus seedlings under both normal and water stress conditions. The above corroborates with that observed in this study since the dose of $2.0 \mu \mathrm{mol} \mathrm{L}-1$ of JA expressed the highest increment in plant height.

Outplanted seedlings showed high growth of stem diameter when submitted to the lower dose of JA (T2) in relation to T4, T6 and to the control (T1). Even presenting smaller mean of stem resistance and stem lignin, seedlings submitted to $2.0 \mu \mathrm{mol} \mathrm{L}^{-1}$ of JA (T2) had higher mean values of increments in height (IAP) and stem diameter (IDC). The results probably contributed to a higher IAP performance in relation to the other doses and of IDC in relation to the control treatment, the dose of $6.0 \mu \mathrm{mol} \mathrm{L}{ }^{-1}$ of JA (T4) and to T6 (twenty stem bending) measured 150 days after field outplanting. 
A work with jasmonates indicated that it induces the production of ethylene in various plant organs (FAN; MATHEIS; FELLMAN, 1998). Hudgins and Franceschi (2004) applying methyl jasmonate in different concentrations in the second node of Pseudotsuga menziesii (Mirb. Franco) var. menziesii seedlings observed ethylene production in the internodes above and below the treated node. According to Kerbauy (2012), ethylene can cause reduced growth because it has the potential to change the plant physiology, such as reduction in auxin transport, reorganization of microtubules and microfibrils of cellulose of cell wall to a longitudinal position causing reduction of height and thickening of the stem. These facts demonstrate the possibility that doses above 2 $\mu \mathrm{mol} \mathrm{L}-1$ of JA sprayed on clone 1528 seedlings stimulated the ethylene production and the field seedling performance.

Dranski (2013) reported different results from this experiment with seedlings of Pinus taeda L. ninety days after field planting with a $25 \%$ increase in the seedling height submitted to thirty-five daily bending per 60 days and a $28.2 \%$ increase in the stem diameter with twentythree bending in comparison to the control treatment. Therefore, the above report indicated that seedlings submitted to stem bending in the nursery showed greater initial growth potential in the field, whereas in this study it did not alter the performance of both IAP and IDC. Dranski (2013) study had seedlings planted in an area subject to strong winds contrary to this experiment. Therefore, different environment conditions evidenced in this study (Figure 3) could have modulated results from those by Dranski (2013). In this experiment seedlings that presented higher concentration of lignin in the stem and greater stem resistance did not express higher field performance (increase in plant height) in relation to the control seedlings.

Other results diverging from this study were reported by Kern et al. (2005) with hybrids of Populus trichocarpa (Torr. \& Gray) and Populus deltoides Bartr. submitted to twenty daily stem bending for 80 days, The above authors found reduction in height and increase in stem diameter compared to the control treatment.

Additionally, Cadorin et al. (2015) with Cordia trichotoma (Vell.) Arrab. ex Steud. seedlings submitted to daily stem bending and of methyl jasmonate observed no increase in height growth rate 90 days after planting. Cadorin et al. (2015) reported that in seedlings submitted to twenty daily stem bending for 60 days exhibited a greater increase in the growth rate of stem diameter $(107 \%)$ in relation to the control seedlings. Furthermore, at 150 days after planting, seedlings submitted to twenty daily stem bending and those submitted to methyl jasmonate for 60 days resulted in higher growth rates in height $(130 \%)$ and stem diameter $(102 \%)$ compared to control seedlings.

In our study, the lack of increase in seedling height and stem diameter compared to control seedlings after planting are probably due to the improved genetic characteristics of the hybrid or, alternately, the synthesis of ethylene resulting from JA.

The multicollinearity analysis (Table 4) yielded condition number (NC) equal to 8.14 and FIV equal to 4.0 indicating weak multicollinearity (CRUZ, 2006). Therefore, the variables were not highly correlated. The path analysis revealed that seedlings with more rigid stems resulted in lower rate of height increase. Considering the coefficients of direct and total effect between those variables were -3.70 and -0.90 respectively, we concluded that the relation is of cause effect, which corroborates with that expressed in Table 1, where T1, T2, T3 and T7 had lower stem resistance values as well as higher rate of height growth (Table 2).

On the other hand, seedlings with more lignified stems, despite having a high value of the direct effect coefficient with the increase in height (3.49) and with the stem diameter (3.53) is affected negatively via the indirect effect of stem resistance (-3.10 and -3.14 , respectively). Therefore, seedlings more lignified result in more rigid stems, which does not favor height and diameter growth. 
Table 4 - Estimation of the direct and indirect effects of track and correlation coefficients for mean stem diameter increment and height in relation to seedling height, stem diameter, lignin in the root, lignin in the stem and flexural rigidity in Eucalyptus clone 1528 seedlings, submitted to the application of jasmonic acid

Tabela 4 - Estimativa dos efeitos diretos e indiretos dos coeficientes de trilha e correlação para média do incremento no diâmetro do caule e altura em relação à altura, diâmetro do coleto, lignina na raiz, lignina no caule e rigidez flexural em mudas de eucalipto clone 1528, submetidas à aplicação de ácido jasmônico

\begin{tabular}{|c|c|c|c|c|c|}
\hline \multirow[b]{2}{*}{ Variables } & \multirow[b]{2}{*}{ Association routes } & \multicolumn{2}{|c|}{ IDC } & \multicolumn{2}{|c|}{ IAP } \\
\hline & & Estimate & $\begin{array}{l}\text { Correlation } \\
\text { coefficient }\end{array}$ & Estimate & $\begin{array}{l}\text { Correlation } \\
\text { coefficient }\end{array}$ \\
\hline \multirow{6}{*}{ AP } & Direct effect & 0,84 & & 0,54 & \\
\hline & Indirect via DC & 0,80 & & 0,95 & \\
\hline & Indirect via LR & $-0,37$ & & $-0,34$ & \\
\hline & Indirect via $\mathrm{LC}$ & $-1,93$ & & $-1,90$ & \\
\hline & Indirect via $\mathrm{RF}$ & 0,69 & & 0,68 & \\
\hline & Total (direct and indirect) & & 0,03 & & $-0,07$ \\
\hline \multirow{5}{*}{ DC } & Direct effect & 1,45 & & 1,72 & \\
\hline & Indirect via $\mathrm{AP}$ & 0,46 & & 0,30 & \\
\hline & Indirect via LR & $-0,38$ & & $-0,35$ & \\
\hline & Indirect via LC & $-2,65$ & & $-2,61$ & \\
\hline & Indirect via $\mathrm{RF}$ & 1,12 & & 1,11 & \\
\hline \multirow{7}{*}{ LR } & Total (direct and indirect) & & 0,01 & & 0,16 \\
\hline & Direct effect & $-0,72$ & & $-0,66$ & \\
\hline & Indirect via AP & 0,43 & & 0,28 & \\
\hline & Indirect via DC & 0,77 & & 0,91 & \\
\hline & Indirect via $\mathrm{LC}$ & $-2,82$ & & $-2,78$ & \\
\hline & Indirect via $\mathrm{RF}$ & 2,72 & & 2,68 & \\
\hline & Total (direct and indirect) & & 0,38 & & 0,42 \\
\hline \multirow{6}{*}{ LC } & Direct effect & 3,53 & & 3,49 & \\
\hline & Indirect via AP & $-0,46$ & & $-0,29$ & \\
\hline & Indirect via $\mathrm{DC}$ & $-1,09$ & & $-1,29$ & \\
\hline & Indirect via $L R$ & 0,57 & & 0,53 & \\
\hline & Indirect via RF & $-3,14$ & & $-3,10$ & \\
\hline & Total (direct and indirect) & & $-0,58$ & & $-0,67$ \\
\hline
\end{tabular}


Table 4 - Conclusion ...

Tabela 4 - Conclusão ...

\begin{tabular}{|c|c|c|c|c|c|}
\hline \multirow[b]{2}{*}{ Variables } & \multirow[b]{2}{*}{ Association routes } & \multicolumn{2}{|c|}{ IDC } & \multicolumn{2}{|c|}{ IAP } \\
\hline & & Estimate & $\begin{array}{l}\text { Correlation } \\
\text { coefficient }\end{array}$ & Estimate & $\begin{array}{c}\text { Correlation } \\
\text { coefficient }\end{array}$ \\
\hline \multirow{6}{*}{$\mathbf{R F}$} & Direct effect & $-3,75$ & & $-3,70$ & \\
\hline & Indirect via AP & $-0,15$ & & $-0,10$ & \\
\hline & Indirect via DC & $-0,44$ & & $-0,52$ & \\
\hline & Indirect via LR & 0,52 & & 0,48 & \\
\hline & Indirect via LC & 2,96 & & 2,93 & \\
\hline & Total (direct and indirect) & & $-0,85$ & & $-0,90$ \\
\hline \multicolumn{2}{|c|}{ Determination coefficient } & 0,91 & & & 0,98 \\
\hline \multicolumn{2}{|c|}{ Condition number (NC) } & 12,75 & & & 8,14 \\
\hline \multicolumn{2}{|c|}{ Inflation variance factor (FIV) } & 3,0 & & & 4,0 \\
\hline
\end{tabular}

Source: Authors (2017)

On what: IAC: height increment; IDC: stem diameter increment; AP: seedling height; DC: stem diameter; LR: root lignin; LC: stem lignin.

In the interpretation of the results obtained from the decomposition of the Pearson linear correlation coefficient (Table 4), we considered that when the correlation coefficient and the direct effect were equal or similar in either magnitude and signal it explained the true association between the variables (VENCOVSKY; BARRIGA, 1992). Thus, when the Pearson correlation coefficient is positive, but the direct effect is negative or negligible, the correlation will be caused by indirect effects. The Pearson correlation coefficient is negligible and the direct effect is positive and with a high value, the indirect effects are responsible for the lack of correlation, deserving the same attention in the analysis. Finally, with Pearson's negative correlation and positive and a high direct effect, we sought to eliminate the indirect effects of the analysis and take advantage of the direct ones only.

The coefficients of determination of 0.91 of height increase and 0.98 of diameter increase demonstrated that almost all variables are explained by morphometric variables and lignin content. Seedling height, stem diameter and root lignin content presented a low positive correlation with the mean increase in stem diameter $(0.03,0.01$ and 0.38$)$ as well as the content of lignin in stem and flexural stiffness presented negative correlation $(-0.58$ and -0.85$)$. For the seedling height, the variables stem diameter and root lignin showed a correlation of low positive magnitude (0.16 and 0.42), while the seedling height, stem lignin and stem resistance presented negative correlation of $-0.07,-0.67$ and -0.90 , respectively.

Thus, the results indicated that morpho-physiological changes resulting from stem bending and jasmonic acid are probably related to the initial performance of seedlings in the field. However, such responses indicate the need for more studies and a better understanding of the use of stem bending and spraying of JA in seedlings that have the capacity of altering the lignin concentration, as well as the performance of the seedlings in the field. However, there is a possibility that application of JA in seedlings of wood species could be used instead of stem bending in the nursery because of the similarity of the physiological responses and the practicality of it. 


\section{Conclusions}

Stem bending and $8.0 \mu \mathrm{mol} \mathrm{L}^{-1}$ of JA applied in Eucalyptus clone 1528 seedlings resulted in a low root lignin content. Lignin content in the stem was influenced by 6.0 and $8.0 \mu \mathrm{mol} \mathrm{L}^{-1}$ of $\mathrm{JA}$, as well as by stem bending resulting in a higher lignin content compared to control seedlings.

The lowest dose of jasmonic acid $\left(2.0 \mu \mathrm{mol} \mathrm{L}^{-1}\right)$ expressed higher increase in seedling height and stem diameter after 150 days of planting.

Path analysis showed a greater direct effect between stem lignin content with mean increase of height and stem diameter in outplanted seedlings.

\section{References}

BHERING, S. B. et al. Mapa de solos do Estado do Paraná: escala 1:250.000: legenda. Rio de Janeiro: EMBRAPA Solos, 2007.

CADORIN, D. A. et al. Metil jasmonato e flexões caulinares na rustificação e crescimento inicial de mudas de Cordia trichotoma. Cerne, Lavras, v. 21, n. 4, p. 657-664, 2015.

CARNEIRO, J. G. A. Produção e controle de qualidade de mudas florestais. Curitiba: UFPR; UENF; FUPEF, 1995. 415 p.

CARVALHO, A. M.; NAHUZ, M. A. R. Valorização da madeira do híbrido Eucalyptus grandis x Eucalyptus urophylla através da produção conjunta de madeira serrada em pequenas dimensões, celulose e lenha. ScientiaForestalis, Piracicaba, n. 59, p. 61-76, 2001.

CAVIGLIONE, J. H. et al. Cartas climáticas do Paraná. Londrina: IAPAR, 2000. CD-ROM.

CRUZ, C. D. Programa genes: aplicativo computacional em genética e estatística. Viçosa, MG: UFV, 2001. 648 p.

CRUZ, C. D. Programa genes: estatística experimental e matrizes. Viçosa, MG: UFV, 2006. 285 p.

DETMANN, E. et al. Métodos para análise de alimentos - INCT - Ciência animal. Visconde do Rio Branco: Suprema, 2012. 214 p.

DRANSKI, J. A. L. Tigmomorfogênese na rustificação e sobrevivência em mudas de Pinus taeda L. 2013. Tese (Doutorado em Agronomia) - Universidade Estadual do Oeste do Paraná, Marechal Cândido Rondon, 2013.

DRANSKI, J. A. L.; MALAVASI, U. C.; MALAVASI, M. M. Relationship between lignin content and quality of Pinus taeda seedlings. Revista Árvore, Viçosa, MG, v. 39, p. 905-913, 2015.

FAN, X.; MATHEIS, J. P.; FELLMAN, J. K. A role for jasmonates in climacteric fruit ripening. Planta, An International Journal of Plant Biology, [s. l.], v. 204, p. 444-449, 1998.

FRANK, S.; ROSS, S. Plant Physiology. 4t ed. California: Wadsworth, 1991. 
HAASE, D. L. Understanding forest seedling quality: measurements and interpretation. Tree Planters Notes, Washington State, v. 52, n. 2, p. 24-30, 2008.

HUDGINS, J. W.; FRANCESCHI, R. V. Methyl jasmonate-induced ethylene production is responsible for conifer phloem defense responses and reprogramming of stem cambial zone for traumatic resin duct formation. Plant Physiology, United States, v. 135, p. 2134-2149, 2004.

INMET- Instituto Nacional de Meteorologia. 2016. Estação Meteorológica de Observação de Superfície Automática, Brasília, DF, Brasil. Disponível em: http://www.inmet.gov.br/portal/ index.php?r=estacoes/mapaEstacoes. Acesso em: 20 de abril de 2017.

JACOBS, D. F.; LANDIS, T. D. Hardening. In: DUMROESE, R. K.; LUNA, T.; LANDIS, T. D. (ed.). Nursery manual for native plants: guide for tribal nurseries. Washington: United States Department of Agriculture, Forest Service, 2009. v.1. p. 217-228.

JAFFE, M. J. Thigmomorphogenesis: the response of plant growth and development to mechanical stimulation with special reference to Bryoniadioica. Planta, An International Journal of Plant Biology, [s. l.], v. 114, n. 2, p. 143-156, 1973.

KAVALIER, A. The effects of methyl jasmonate on the anthocyanin content and growth rates of the Wisconsin fast plants Brassicarapa. Research preformed at the College of Charleston. Charleston: College of Charleston, 2000.

KERBAUY, G. B. Fisiologia vegetal.2. ed. Rio de Janeiro: Guanabara Koogan, 2012.

KERN, A. K. et al. Mechanical perturbation affects conductivity, mechanical properties and aboveground biomass of hybrid poplars. Tree Physiology, Oxford, v. 25, n. 10, p. 1243-1251, 2005.

MALAVASI, U. C.; DAVIS, A. S.; MALAVAS, M. M. Lignin in Woody Plants under Water Stress: A Review. Revista Floresta e Ambiente, Rio de Janeiro, v. 23, n. 4, p. 589-597, 2016.

MARDANI, H. et al. Assessment of salicylic acid impacts on seedling characteristic of cucumber (Cucumis sativus L.) under water stress. Notulae Scientia Biologicae, Cluj-Napoca, v. 4, n. 1, p. 112-115, 2012.

MARTIN, L. et al. Acclimation kinetics of physiological and molecular responses of plants to multiple mechanical loadings. Journal of Experimental Botany, Oxford, v. 61, n. 1, p. 2403-2412, 2010.

MAZZUCHELLI, E. H. L.; SOUZA, G. M.; PACHECO, A. C. Rustifcação de mudas de eucalipto via aplicação de ácido salicílico. Pesquisa Agropecuária Tropical, Goiânia, v. 44, n. 4, p. 443-450, 2014.

MONTEIRO, M. B. O.; PEREIRA, R. P. W.; ABREU, H. S. Compositonal Analysis of the lignina of Eucalyptus urophylla treated with JA e 2,4-D. Biochemistry and Biotechnology Reports, Londrina, v. 1, n. 2, p. 48-56, 2012.

OLIVEIRA, M. B.; ABREU, H. S.; PEREIRA, R. P. W. Teor de lignina em plantas de Eucalyptus urophylla S. T. Blake tratadas com fitorreguladores. Silva Lusitana, Portugal, v. 17, n. 1, p. 51-57, 2009.

ORO, P. et al. Aplicação de regulador vegetal na aclimatação de mudas de Cariniana estrellensi. Cultivando o Saber, Cascavel, v. 5, n. 4, p. 103-112, 2011.

PANDOLFI, F. Avaliação de parâmetros de rusticidade de mudas clonais de eucalipto e suas influências no crescimento inicial do povoamento. 2009. Dissertação (Mestrado em Agronomia) - Universidade Federal do Espírito Santo, Alegre, 2009.

PORTAL FLORESTAL. Clone - AEC 1528 - Super Clone. São Paulo, [2016]. Disponível em: http://www.portalflorestal.com.br/portfolio/mudas-de-eucalipto-clonado-a-venda-clone-aec1528-super-clone/. Acesso em: 08 nov. 2016. 
PORTER, B. W. et al. Novel thigmomorphogenetic responses in Carica papaya: touch decreases anthocyanin levels and stimulates petiole cork outgrowths. Annals of Botany, Oxford, v. 103, n. 1, p. 847-858, 2009.

RITCHIE, G. A. et al. Assessing plant quality. In: LANDIS, T. D. et al.The container tree nursery manual: seedling processing, storage, and outplanting. Washington: USDA Forest Service, 2010. p. $18-81$.

SANCHEZ, F. Jasmonatos: compuestos de alto valor para la agricultura: actividad biológica y rutabio sintética del ácido jasmónicoen plantas. Revista ICIDCA, La Habana, v. 42, n. 1/3, p. 51-59, 2008.

SANTOS, H. G. et al. Sistema brasileiro de classificação de solos. 3. ed. Brasília: EMBRAPA, 2013. $353 \mathrm{p}$.

TAIZ, L.; ZEIGER, E. Fisiologia vegetal. 5. ed. Porto Alegre: Artmed, 2013. 954 p.

TELEWSKI, F. W. Is windswept tree growth negative Thigmotropism? Plant Science, [s. l.], n. 184, p. 20-28, 2012.

VENCOVSKY, R.; BARRIGA, P. Genética biométrica no fitomelhoramento. Revista Brasileira de Genética, Ribeirão Preto, p. 496, 1992.

VOLKWEIS, R. C. et al. Efeito da tigmomorfogênese na morfometria de mudas de Maytenus ilicifolia (Schrad.) Planch. Ciência Florestal, Santa Maria, v. 24, n. 2, p. 339- 342, 2014. 